Endocrinol. Japon. 1985, 32 (1), 65-72

\title{
Production of Anti-Human Thyroglobulin and Anti-Thyroid Hormone Antibodies in Rabbits Immunized with Human Thyroglobulin
}

\author{
Shigeki SAKATA, ShIgenori NAKAMURA, TAKashi KOMAKI \\ AND KIYOSHI MIURA
}

The Third Department of Internal Medicine, Gifu University School of Medicine, Gifu, 500

\begin{abstract}
Two rabbits (TG-1, TG-2) were immunized with human thyroglobulin (HTg) and bled serially. Antisera were obtained at different times after the first immunization and kept separately and studied. In both rabbits production of anti-HTg, and anti-thyroid hormone antibodies such as anti-thyroxine (T4) and anti-triiodothyronine (T3) antibodies was observed. Binding parameters of antiHTg antibodies with HTg, T4, and T3 were calculated in two selected antisera (70-day and 249-day). The Scatchard's plots of these antibodies were all curvelinear and were analyzed in two components: one, higher binding constant (Ka1) and smaller binding capacity (Cap1) and the other, lower binding constant (Ka2) and larger binding capacity (Cap2). Ka1 values of anti-HTg, anti-T4, and anti-T3 antibodies in sera from TG-1 obtained from 70-day and 249-day bleeding were $1.1 \times 10^{10} \mathrm{M}^{-1}, 6.0 \times 10^{9} \mathrm{M}^{-1}$. $7.9 \times 10^{8} \mathrm{M}^{-1}$ and $1.7 \times 10^{10} \mathrm{M}^{-1}, 6.5$ $\times 10^{9} \mathrm{M}^{-1}, 1.0 \times 10^{9} \mathrm{M}^{-1}$, respectively. Those from TG-2 were $1.7 \times 10^{10} \mathrm{M}^{-1}, 1.8 \times$ $10^{9} \mathrm{M}^{-1}, 6.4 \times 10^{8} \mathrm{M}^{-1}$ and $2.0 \times 10^{10} \mathrm{M}^{-1}, 3.1 \times 10^{9} \mathrm{M}^{-1}, 1.6 \times 10^{9} \mathrm{M}^{-1}$, respectively.

The significance of the production of anti-HTg and anti-thyroid hormone antibodies in rabbits immunized with $\mathrm{HTg}$ in relation to the antigenic structure of HTg molecule was discussed.
\end{abstract}

Since Robbins et al. (1956) first reported the presence of anti-T4 antibodies in the sera of a patient with papillary carcinoma who had been treated with ${ }^{131} \mathrm{I}$, the presence of anti-thyroid hormone antibodies has been reported in various thyroidal and nonthyroidal disorders. These include Hashimoto's thyroiditis (Premachandra and Blumentha1, 1967; Ochi et al., 1972; Staeheli et al., 1975; Herrmann et al., 1977 ; Ikekubo et al., 1978; Ginsberg et al., 1978; Nakamura et al., 1982), hypothyroidism during

Received September 17, 1984 desiccated thyroid hormone treatment (Staeheli et al., 1975), Graves' disease (Staeheli et al., 1975; J $\phi$ grensen et al., 1970; Inada et al., 1980; Moroz et al., 1983; Sakata et al., 1985) and Waldenström's macroglobulinemia (Trimarchi et al., 1982).

Thyroid hormones are haptens and are not immunogenic in free form. However, when conjugated with macromolecules such as albumin, they can initiate antibody formation. The presence of such macromolecules is essential for the production of antithyroid hormone antibodies. This aspect of the relationship between anti-HTg antibodies 
and anti-thyroid hormone antibodies has been discussed by many workers (Ochi et al., 1972; Herrmann et al., 1977 ; Hehrmann et al., 1977; Pudek and McIntosh, 1981), since HTg molecule contains considerable amounts of T4 and T3 (Izumi and Larsen, 1977).

Premachandra et al. (1963) first demonstrated the production of anti-thyroid hormone antibodies as well as lesions of autoimmune thyroiditis in guinea pigs immunized with bovine thyroglobulin. Later, Ochi et al. (1972) immunized 15 rabbits with HTg but the production of anti-thyroid hormone antibodies was observed in none of them. Huwever, immunization with denatured HTg with either heat, acid or alkaline treatment raised anti-thyroid hormone antibodies in 12 out of 12 rabbits. Thus, controversy still exists concerning the production of anti-thyroid hormone antibodies in animals immunized with native thyroglobulin.

In order to clarify the mechanism(s) of the production of anti-thyroid hormone antibodies observed in thyroidal and nonthyroidal disorders, we have immunized two rabbits with HTg purified without steps which could induce denaturation of HTg (native $\mathrm{HTg}$ ) and we examined the production of anti-HTg and anti-thyroid hormune antibodies in them.

\section{Materials and Methods}

\section{Purification of HTg.}

Purified HTg was a gift from Dr. Tarutani. It was purified according to the method reported by Ui and Tarutani (1961). Although we have not measured the content of iodothyronines, purified HTg contained $0.38 \%$ of iodine $/ \mathrm{HTg}$ (w/w \%). On this iodine concentration, content of T3 and T4 are roughly estimated 0.5 and 1.0 residue/mol of $\mathrm{HTg}$, respectively (Tarutani et al., 1975).
2. Quantification of anti-HTg and anti-thyroid hormone antibodies.

Two outbred female rabbits (10 weeks after birth; TG-1, TG-2) were immunized with 0.5 $\mathrm{mg}$ of HTg emulsified with $1.0 \mathrm{ml}$ of Freund's complete adjuvant (FCA) according to the same immunization schedule. The immunizations were either intramuscular and subcutaneous (days 0, 70 ) or only subcutaneous (days 10,19, 115, 190, and 210). The rabbits were bled at different times after the first immunization (from 26 days up to 249 days). Antisera in the serial bleeding from each rabbit were not mixed and were kept separately in the frozen state $\left(-20^{\circ} \mathrm{C}\right)$. Selected antisera from both rabbits; 70-day and 249-day, were studied in the present work.

Quantification of anti-HTg antibodies was carried out by the solid phase radioimmunoassay (RIA) using ${ }^{125}$ I-protein A developed and evaluated in our laboratory (Sakata et al., 1983 a). Briefly, polystylene tubes were coated with $\mathrm{HTg}$, followed by the addition of diluted antisera. After washing with phosphate-buffered saline (PBS, pH 7.4), bound anti-HTg antibodies on the tubes were detected with ${ }^{125} \mathrm{I}$-protein $\mathrm{A}$. Titers of anti-HTg antibodies were expressed as percentage of bound ${ }^{125}$ I-protein A.

Quantification of anti-T4 and anti-T3 antibodies in both rabbits was done as follows. Twenty-five microliters of antisera obtained by serial bleeding was incubated at $25^{\circ} \mathrm{C}$ for 16 hours with $25 \mu \mathrm{l}$ of ${ }^{125} \mathrm{I}-\mathrm{T} 4(40 \mathrm{pg}, 40,000 \mathrm{cpm})$ or T3 $(40 \mathrm{pg}, 32,000 \mathrm{cpm})$ and $950 \mu 1$ of $0.06 \mathrm{M}$ barbital buffer (pH 8.6) containing 8-anilino-1naphthalene-sulfonic acid (ANS, Wako Chemicals, Osaka) at the concentration of $63 \mathrm{mM}$. After incubation, an equal amount of $(1.0 \mathrm{ml})$ $25 \%$ polyethylene glycole (PEG, M.W. : 7,500, Wako Chemicals, Osaka) that had been dissolved in PBS was added. After centrifugation at $3,000 \mathrm{G}$ for $20 \mathrm{~min}$. at $25^{\circ} \mathrm{C}$, the supernatant was aspirated and radioactivity of the precipitated $\gamma$-globulin was counted. Then bound radioactivity of ${ }^{125} \mathrm{I}-\mathrm{T} 4$ or ${ }^{125} \mathrm{I}-\mathrm{T} 3$ to immune sera was subtracted from that of preimmune sera and was divided by total radioactivity of the added ${ }^{125} \mathrm{I}-$ T4 or ${ }^{125} \mathrm{I}-\mathrm{T} 3$. They are expressed as $\%$ bound.

\section{Characterization of anti-HTg and anti-thyroid hormone antibodies.}

Anti-HTg antisera from each rabbit obtained at 70-day and 249-day were diluted with PBS to $10^{-4}$, respectively. To $50 \mu 1$ of diluted antisera, 
$50 \mu 1$ of ${ }^{125} \mathrm{I}-\mathrm{HTg}$, cold $\mathrm{HTg}$ of different concentrations and $50 \mu 1$ of $0.5 \%$ normal rabbit serum were added and were incubated for 16 hours at $25^{\circ} \mathrm{C}$, followed by the addition of 50 $\mu 1$ of goat anti-rabbit $\gamma$-globulin. This was followed by another incubation for 16 hours at $25^{\circ} \mathrm{C}$. The mixture was then centrifuged at $3,000 \mathrm{G}$ for $30 \mathrm{~min}$. at $25^{\circ} \mathrm{C}$. After aspiration of the supernatant, the radioactivity of the precipitate was counted and the association constant between HTg and anti-HTg antibodies was calculated.

The characterization of anti-T4 and anti-T3 antibodies was done as follows. Twenty-five microliters of rabbit anti-HTg antisera was incubated at $25^{\circ} \mathrm{C}$ for 16 hours either with ${ }^{125} \mathrm{I}-\mathrm{T} 4$ (40 pg, 40,000 cpm) or ${ }^{125} \mathrm{I}-\mathrm{T} 3(40 \mathrm{pg}, 32,000 \mathrm{cpm})$ together with different concentrations of cold T4 or T3, and $800 \mu l$ of phosphate buffer $(\mu=0.16$, $\mathrm{pH}$ 7.4) with ANS at a concentration of $63 \mathrm{mM}$. After incubation, the $\gamma$-globulin fraction was precipitated with $12.5 \%$ PEG and the association constant $(\mathrm{Ka})$ was calculated using Scatchards' plots.

${ }^{125} \mathrm{I}-\mathrm{T} 4$ and ${ }^{125} \mathrm{I}-\mathrm{T} 3$ with specific activities of $1160 \mu \mathrm{Ci} / \mu \mathrm{g}$ and $1250 \mu \mathrm{Ci} / \mu \mathrm{g}$, respectively, were obtained from New England Nuclear. Radioiodination of HTg and protein A (Sigma Chemicals) was performed according to the chloramine $\mathrm{T}$ method using ${ }^{125} \mathrm{INa}$ (Amersham, UK). Specific activities of ${ }^{125} \mathrm{I}-\mathrm{HTg}$ and ${ }^{125} \mathrm{I}$-protein A was $4-6 \mu \mathrm{Ci} / \mu \mathrm{g}$ and $8-10 \mu \mathrm{Ci} / \mu \mathrm{g}$, respectively. T4 and T3 were purchased from Sigma Chemi- cals and were further purified with HPLC before use.

\section{Results}

1. Time course studies of the production of anti-HTg and anti-thyroid hormone antibodies.

As shown in Fig. 1, 2, and 3, titers of anti-HTg, anti-T4, and anti-T3 antibodies increased with immunization in both rabbits.

\section{Physicochemical parameters of anti-HTg antibodies.}

In order to examine the physicochemical parameters of anti-HTg as well as antithyroid hormone antibodies, early antisera (70-day bleeding) and hyperimmune antisera (249-day bleeding) from both rabbits were selected for the investigation. Fig. 4 indicates the results. Using Scatchard's plots, anti-HTg antibodies were analyzed in two components: one, higher binding constant (Ka 1) and smaller binding capacity (Cap 1) and the other, lower binding constant (Ka 2) and larger binding capacity (Cap 2). As summarized in Table $1, \mathrm{Ka} 1$ and $\mathrm{Ka} 2$ values for early antisera and hyperimmune antisera

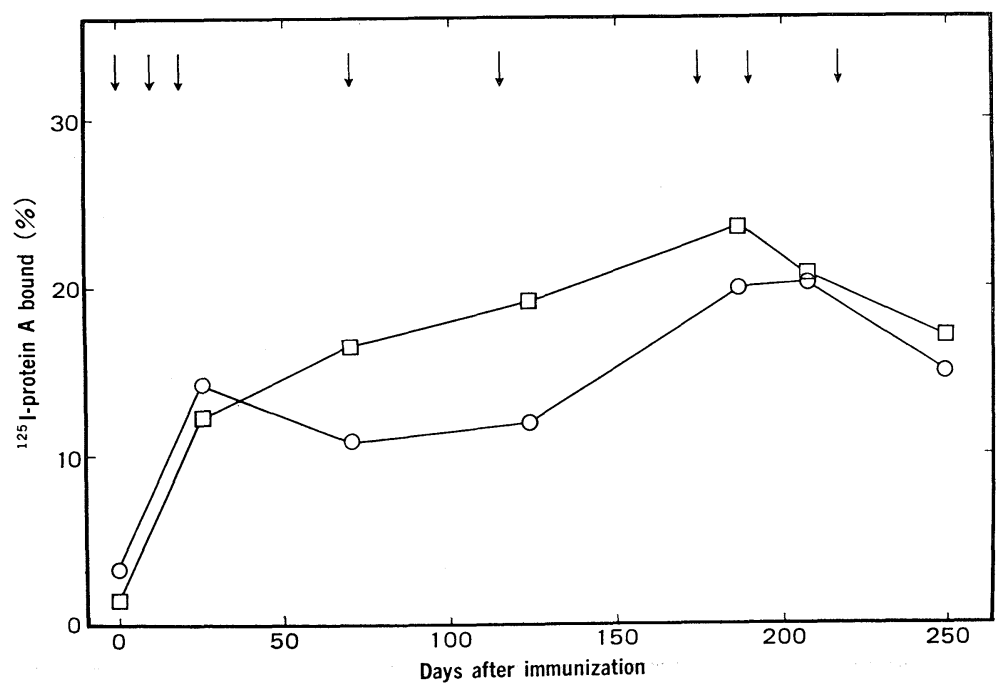

Fig. 1. Time course changes in the titers of anti-HTg antibodies in rabbits immunized with HTg (TG1, TG-2). Each antiserum was diluted to $10^{-3}$ with PBS and $50 \mu 1$ of diluted antisera was added to the tubes which had been coated with HTg. Detection of the anti-HTg antibodies was done with ${ }^{125} \mathrm{I}$-protein A. Arrows indicate immunization schedule. ( $\bigcirc)$ antisera from rabbit TG-1:( $\square$ ) antisera from rabbit TG-2. 
of TG-1 are $1.1 \times 10^{10} \mathrm{M}^{-1}$ and $4.8 \times 10^{8}$ $\mathrm{M}^{-1}, \quad 1.7 \times 10^{10} \mathrm{M}^{-1}$ and $2.2 \times 10^{8} \mathrm{M}^{-1}$, and those of TG-2 are $1.7 \times 10^{10} \mathrm{M}^{-1}$ and $1.0 \times$ $10^{9} \mathrm{M}^{-1}, 2.0 \times 10 \mathrm{M}^{-1}$ and $1.6 \times 10^{9} \mathrm{M}^{-1}$, respectively.

3. Physicochemical parameters for antithyroid hormone antibodies.

Physicochemical parameters for anti-T4 and anti-T3 antibodies in rabbits immunized with HTg were also examined using early and hyperimmune antisera. Fig. 5 indicates a typical experiment on inhibition of the binding of 125I-T4 to anti-HTg antibodies by cold T4. In the right panel, Scatchard's plots of interactions between T4 and antiHTg antibodies are shown. Anti-T4 antibodies were also analyzed in two components using Scatchard's equation. Values for $\mathrm{Ka} 1$, Ka 2, Cap1, and Cap 2 thus obtained from two rabbits are summarized in Table 1. $\mathrm{Ka} 1$ and $\mathrm{Ka} 2$ values for anti-T4 antibodies
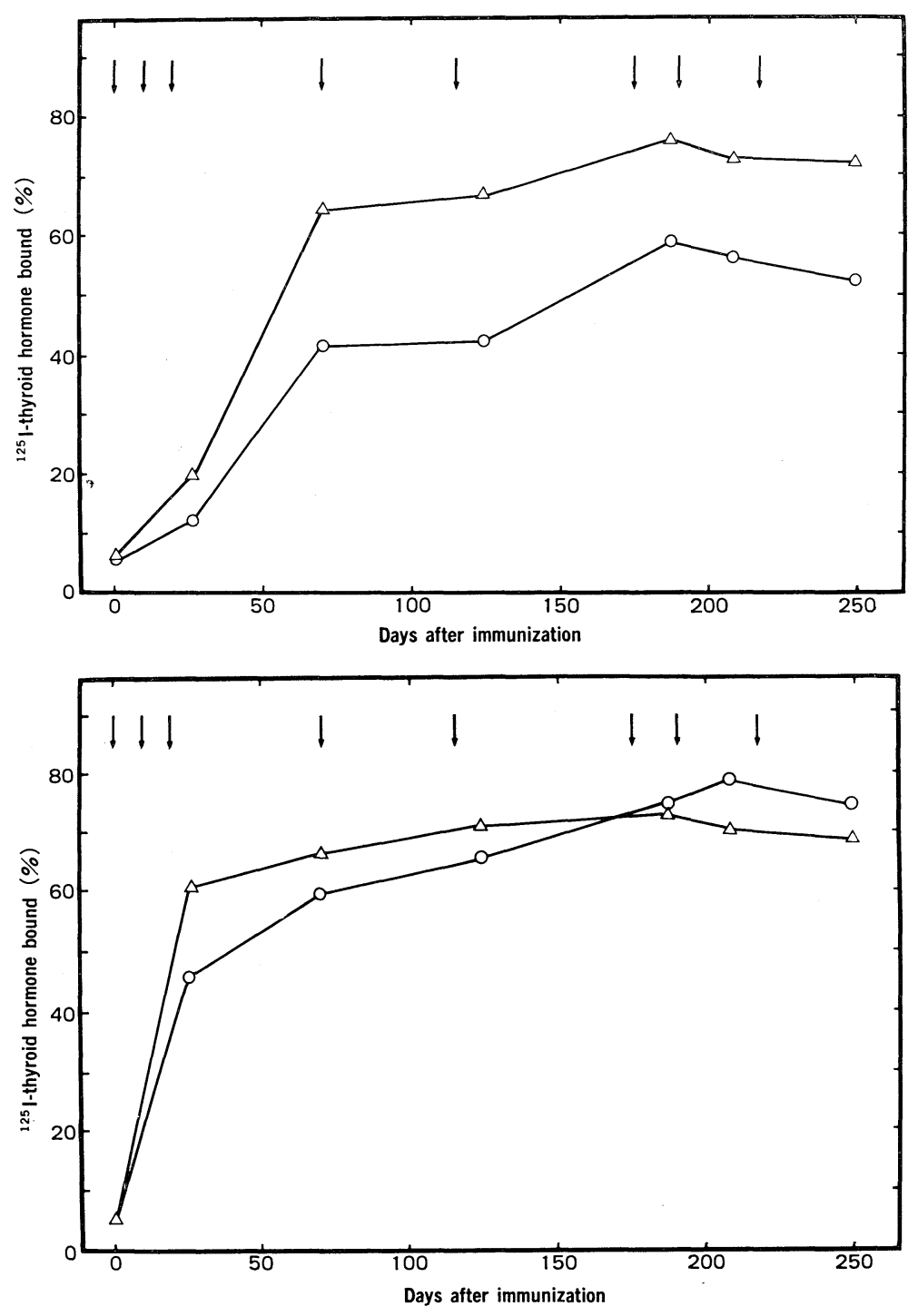

Fig. 2. Time course studies of anti-thyroid hormone antibody activities in sera obtained from rabbit TG1. $(\triangle)$ anti-T4 activities : (O) anti-T3 activities.

Fig. 3. Time course studies of anti-thyroid hormone antibody activities in sera obtained from rabbit TG2. $(\triangle)$ anti-T4 activities : ( $\bigcirc)$ anti-T3 activities. 
varied between $1.8-6.5 \times 10^{9} \mathrm{M}^{-1}$ and $0.73-$ $2.2 \times 10^{8} \mathrm{M}^{-1}$, respectively, which were approximately one-half to one-tenth lower than those for anti-HTg antibodies. Fig. 6 indicates a typical experiment on inhibition of the binding of 125I-T3 to anti-HTg antibodies by cold T3. In the right panel, Scatchard's plots of interactions between $\mathrm{T} 3$ and antiHTg antibodies are shown. Values for Ka 1, $\mathrm{Ka}$ 2, Cap1, and Cap2 thus obtained from the rabbits are summarized in Table $1 . \mathrm{Ka} 1$ and $\mathrm{Ka} 2$ values for anti-T3 varied between $0.79-1.6 \times 10^{9} \mathrm{M}^{-1}$ and $0.2-28 \times 10^{7} \mathrm{M}^{-1}$, respectively, which were without exception lower than those for respective anti-T4 antibodies. Thus the binding constants for antiHTg antisera with HTg, T4, and T3 were strongest in $\mathrm{HTg}$ and lowest in T3. Binding capacities of anti-T4 and anti-T3 antibodies were a pproximately $10^{2}-10^{3}$ magnitudes lower than those of respective anti-HTg antibodies. Another interesting result was that $\mathrm{Ka} 1$ values for anti-HTg, anti-T4, and anti-T3 antibody activities in anti-HTg antisera from both rabbits increased with immunization.

\section{Discussion}

Circulating autoantibodies to thyroid hormone have been found in various thyroidal and non-thyroidal illnesses. This was first reported by Robbins et al. (1956) in a patient with papillary carcinoma of the thyroid treated with 131I. Later, Premachandra et al. (1967) demonstrated the presence of autoantibodies to thyroid hormone in patients with Hashimoto's thyroiditis. Reports accumulated up to the present suggest that spontaneous occurrence of antibodies to T4 and/or T3 in humans may not be a rare phenomenon, especially in patients with Hashimoto's thyroiditis. However, the question remains: what is an antigen(s) of anti-thyroid hormone antibodies?

Premachandra et al. (1963) first demonstrated the production anti-thyroid hormone antibodies as well as lesions of autoimmune thyroiditis in guinea pigs by immunization with bovine Tg-FCA mixture. Ochi et al. (1972), on the other hand, have shown that denatured HTg produced anti-thyroid hormone antibodies in rabbits but native HTg did not. Furthermore, titers of anti-thyroid hormone antibodies in the serum of his patient with Hashimoto's thyroiditis decreased after absorption with HTg. Recently, Pearce et al. (1981) reported a case of hypothyroidism associated with anti-thyroid

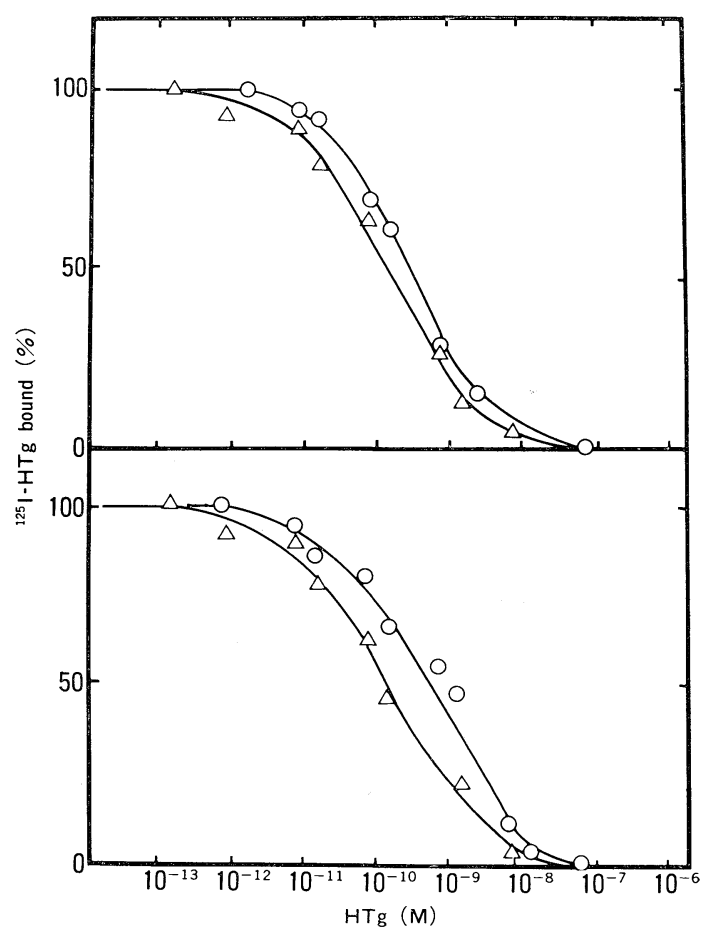

Fig. 4. Inhibition curve of the binding of ${ }^{125} \mathrm{I}-$ HTg with anti-HTg antisera TG-1 (upper panel) and TG-2 (lower panel) by cold HTg. Early antisera (70-day bleeding: $\bigcirc$ ) and hyperimmune antisera (249-day bleeding: $\triangle$ ) were diluted to $10^{-4}$ with PBS, followed by addition of ${ }^{125} \mathrm{I}-\mathrm{HTg}\left(2.9 \times 10^{-12} \mathrm{M}, \quad 44,000\right.$ cpm) and cold HTg of different concentrations. This was further followed by addition of goat anti-rabbit $\gamma$-globulin. After centrifugation radioactivity of the precipitated ${ }^{125} \mathrm{I}-$ HTg with $\gamma$-globulin was counted. 
hormone antibodies and demonstrated that their antigen is in fact the HTg molecule itself.

We agree with the results of Premachandra et al. (1963). Although we have not examined the thyroid pathology of both rabbits, our present investigation shows that anti-thyroid hormone antibodies can be produced by immunization with native HTg molecule. Other possibilities, for example, as speculated by Hehrmann et al. (1977) that thyroid hormones are bound with serum proteins such as immunoglobulin in certain pathological conditions and exhibited antigenicity in some patients cannot be excluded, the results obtained from our experiments further strengthen the possibility that the antigen of anti-thyroid hormone antibodies in at least some patients could be the HTg molecule.

Table 1. Physicochemical parameters of anti-HTg, anti-T4, and anti-T3 antibodies in two rabbits immunized with HTg. Results obtained from early antisera (70-day breeding) and hyperimmune antisera (249-day bleeding) are shown.

\begin{tabular}{|c|c|c|c|c|c|c|}
\hline & \multicolumn{6}{|c|}{$\mathrm{TG}-1$} \\
\hline & \multicolumn{3}{|c|}{ 70-day bleeding } & \multicolumn{3}{|c|}{ 249-day bleeding } \\
\hline & HTg & $T_{4}$ & $T_{3}$ & $\mathrm{HTg}$ & $\mathrm{T}_{4}$ & $T_{3}$ \\
\hline $\mathrm{Ka}_{1}\left(\mathbf{M}^{-1}\right)$ & $1.1 \times 10^{10}$ & $6.0 \times 10^{9}$ & $7.9 \times 10^{8}$ & $1.7 \times 10^{10}$ & $6.5 \times 10^{9}$ & $1.0 \times 10^{9}$ \\
\hline $\mathrm{Ka}_{2}\left(M^{-1}\right)$ & $4.8 \times 10^{8}$ & $1.1 \times 10^{8}$ & $2.2 \times 10^{6}$ & $2.2 \times 10^{8}$ & $2.2 \times 10^{8}$ & $3.7 \times 10^{7}$ \\
\hline $\mathrm{Cap}_{1}(\mathrm{~mol} / \mathrm{m} \ell)$ & $7.8 \times 10^{-6}$ & $8.4 \times 10^{-8}$ & $1.6 \times 10^{-8}$ & $2.4 \times 10^{-5}$ & $1.6 \times 10^{-8}$ & $1.9 \times 10^{-8}$ \\
\hline $\mathrm{Cap}_{2}(\mathrm{~mol} / \mathrm{m} \ell)$ & $27.0 \times 10^{-6}$ & $54.0 \times 10^{-8}$ & $17.9 \times 10^{-8}$ & $14.0 \times 10^{-5}$ & $17.9 \times 10^{-8}$ & $15.6 \times 10^{-8}$ \\
\hline
\end{tabular}

\begin{tabular}{|c|c|c|c|c|c|c|}
\hline & \multicolumn{6}{|c|}{ TG-2 } \\
\hline & \multicolumn{3}{|c|}{ 70-day bleeding } & \multicolumn{3}{|c|}{ 249-day bleeding } \\
\hline & HTg & $\mathrm{T}_{4}$ & $T_{3}$ & HTg & $\mathrm{T}_{4}$ & $T_{3}$ \\
\hline $\mathrm{Ka}_{1}\left(\boldsymbol{M}^{-1}\right)$ & $1.7 \times 10^{10}$ & $1.8 \times 10^{9}$ & $6.4 \times 10^{8}$ & $2.0 \times 10^{10}$ & $3.1 \times 10^{9}$ & $1.6 \times 10^{9}$ \\
\hline $\mathrm{Ka}_{2}\left(\boldsymbol{M}^{-1}\right)$ & $1.0 \times 10^{9}$ & $7.3 \times 10^{7}$ & $3.5 \times 10^{7}$ & $1.6 \times 10^{9}$ & $1.7 \times 10^{8}$ & $2.8 \times 10^{8}$ \\
\hline $\mathrm{Cap}_{1}(\mathrm{~mol} / \mathrm{m} \ell)$ & $1.3 \times 10^{-5}$ & $3.0 \times 10^{-7}$ & $4.8 \times 10^{-8}$ & $5.8 \times 10^{-6}$ & $1.2 \times 10^{-7}$ & $5.6 \times 10^{-8}$ \\
\hline $\mathrm{Cap}_{2}(\mathrm{~mol} / \mathrm{m} \ell)$ & $9.4 \times 10^{-5}$ & $12.1 \times 10^{-7}$ & $50.8 \times 10^{-8}$ & $20.6 \times 10^{-6}$ & $11.6 \times 10^{-7}$ & $27.6 \times 10^{-8}$ \\
\hline
\end{tabular}
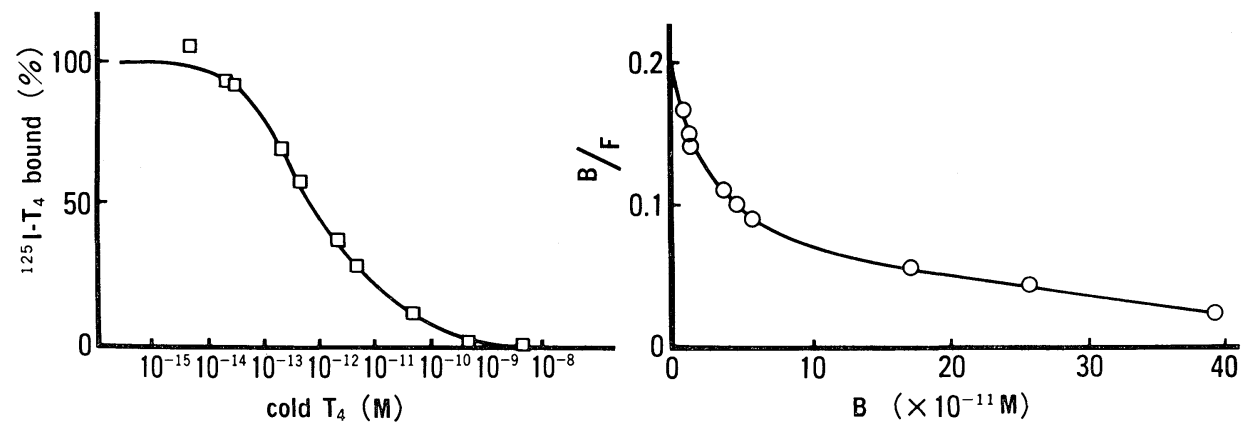

Fig. 5. Characterization of anti-T4 antibodies in TG-2 (249-day bleeding). Left panel indicates the displacement of ${ }^{125} \mathrm{I}-\mathrm{T} 4$ by cold T4. Right panel shows the Scatchard's plots for the same experiment. Details of the experiments are given in the text. 

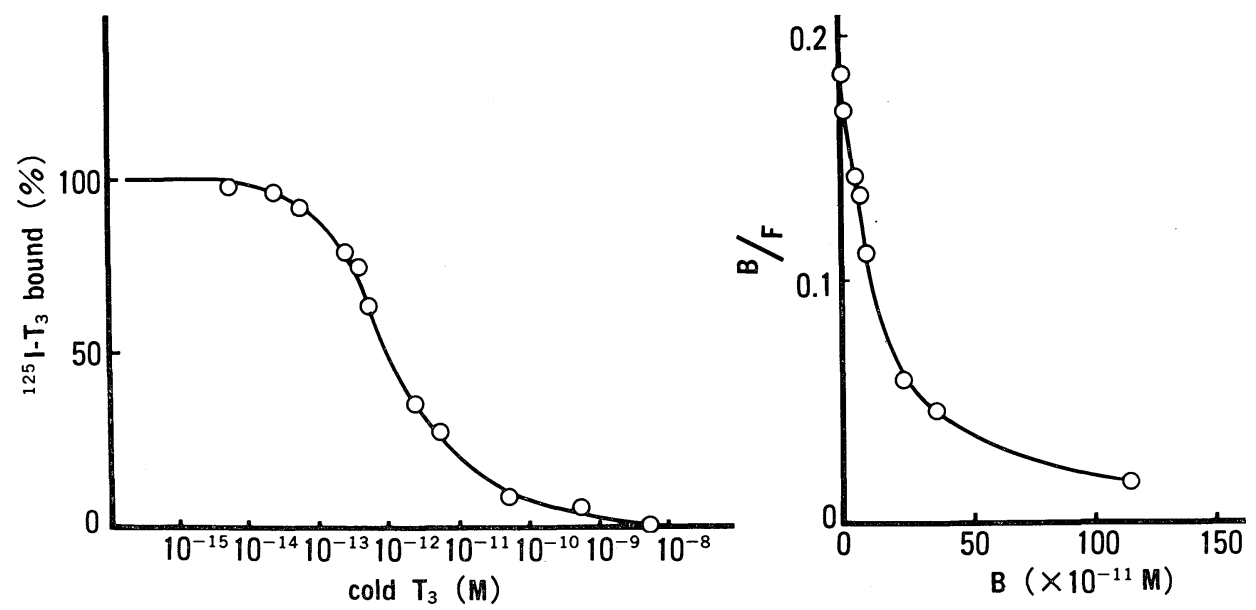

Fig. 6. Characterization of anti-T3 antibodies in TG-1 (249-day bleeding). Left panel indicates the displacement of ${ }^{125} \mathrm{I}-\mathrm{T} 3$ by cold T3. Right panel shows the Scatchard's plots for the same experiment.

The fact that the binding constant and binding capacities of anti-thyroid hormone antibodies were lower than those of antiHTg antibodies, being one-half to one-tenth and $10^{2}$ to $10^{3}$ magnitudes, respectively, suggests that thyroid hormone in the HTg molecule does not possess high antigenicity. We have recently reported the presence of genetic control of the production of antithyroid hormone antibodies in mice immunized with native HTg (Sakata et al., 1983b). Thus, such lower antigenicity of thyroid hormone in HTg molecule together with the participation of immune response genes (Ir-genes) may explain why we cannot detect anti-thyroid hormone antibodies in all sera but can in some patient's sera in which anti-HTg antibodies are positive.

\section{Acknowledgement}

We wish to thank Dr. Tarutani for sending us purified HTg. We also wish to thank Ms. Keiko Hirata and Mr. Yuukoo Yamada for skillful technical assistance. This work was supported by a grant from the Ministry of Health and Welfare's "Disorders of adrenal hormone" Research Committee, Japan.

\section{References}

Ginsberg, J., D. Segal, R. M. Ehrlich and P. G. Walfish (1978). Inappropriate triiodothyronine $\left(\mathrm{T}_{3}\right)$ and thyroxine $\left(\mathrm{T}_{4}\right)$ radioimmunoassay levels secondary to circulating thyroid hormone autoantibodies. Clin. Endocrinol. (Oxf.) 8, 133-139.

Hehrmann, R., B. Höffken, A. von zur Mühlen, H. Creutzig, J. Thiele and R. D. Hesch (1977). Antithyroid hormone autoantibodies under experimental and clinical conditions. Horm. Metab. Res., 9, 326-332.

Herrmann, J., K. H. Rudorff, H. Kroner and B. N. Premachandra (1977). Antibody binding of thyroid hormone in juvenile goitrous hypothyroidism. Horm. Metab. Res., 9, 394-400.

Ikekubo, K., J. Konishi, K. Endo, K. Nakajima, T. Okuno, K. Kasagi, T. Mori, I. Nagata and K. Torizuka (1978). Anti-thyroxine and anti-triiodothyronine antibodies in three cases of Hashimoto's thyroiditis. Acta Enidocrinol. (Copenh.) 89, 557-566.

Inada, M., M. Nishikawa, K. Naito, M. Oishi, S. Kurata and H. Imura (1980). Triiodothyronine-binding immunoglobulin in a patient with Graves' disease and its effect on metabolism and radioimmunoassay of triiodothyronine. Am. J. Med. 68, 787-792.

Izumi, M. and P. R. Larsen (1977). Triiodothyronine, thyroxine, and iodine in purified 
thyroglobulin from patients with Graves' disease. J. Clin. Invest. 59, 1105-1112.

J $\phi$ rgensen, P. H., L. Skovsted and K. A. Jensen (1979). Abnormal gamma globulin binding of thyroid hormones. Acta. Med. Scand. 205, 375-378.

Moroz, L.A., S.J. Meltzer and C. H. Bastomsky (1983). Thyroid disease with monoclonal (Immunoglobulin $\mathrm{G} \lambda$ ) antibody to triiodothyronine and thyroxine. J. Clin. Endocrinol. Metab. 56, 1009-1015.

Nakamura, S., K. Fushimi, M. Okuyama and K. Miura (1982). A study on anti- $T_{3}$ and anti- $\mathrm{T}_{4}$ autoantibodies found in two sisters with juvenile hypothyroidism due to Hashimoto's thyroiditis. Folia. Endocrinol. Jap. 58, 9-23.

Ochi, Y., K. Shiomi, T. Hachiya, M. Yoshimura and T. Miyazaki (1972). Immunological analysis of abnormal binding of thyroid hormone in the gamma-globulin. J. Clin. Endocrinol. Metab. 35, 743-752.

Pearce, C. J., P. G. H. Byfield, C. J. Edmonds, M. R. A. Lalloz and R. L. Himsworth (1981). Autoantibodies to thyroglobulin cross reacting with iodothyronines. Clin. Endocrinol. (Oxf.) 15, 1-10.

Premachandra, B. N., A. K. Ray and H. T. Blumenthal (1963). Effect of thyroglobulin immunization on thyroid function and morphology in the guinea pig. Endocrinology 73, 145-154.

Premachandra, B. N. and H. T. Blumenthal (1967). Abnormal binding of thyroid hormone in sera from patients with Hashimoto's disease. $J$. Clin. Endocrinol. Metab. 27, 931-936.

Pudek, M. R. and H. W. McIntosh (1981). Triiodothyronine-binding immunoglobulin in a euthyroid patient. Clin. Biochem. 14, 142145.
Robbins, J., J. E. Rall and R. W. Rawson (1956). An unusual instance of thyroxine-binding by human serum gamma globulin. J. Clin. Endocrinol. Metab. 16, 573-579.

Sakata, S., S. Nakamura, K. Kamikubo, N. Kojima, M. Okuyama, H. Sato, S. Kashiwamata, O. Tarutani and K. Miura (1983a). A solid phase radioimmunoassay using ${ }^{125} \mathrm{I}-$ protein A for the detection of anti-human thyroglobulin antibodies. Folia. Endocrinol. Jap. 59, 815-823.

Sakata, S., Y. Aihara, K. Okuda, S. Nakamura, K. Kamikubo, T. Komaki, N. Kojima O. Tarutani and K. Miura (1983b). An investigation on the mechanism(s) of the production of antithyroid hormone antibodies. 2. Folia. Endocrinol. Jap. 59, 1729-1737.

Sakata, S., T. Komaki, S. Nakamura, K. Kamikubo, K. Takakuwa, M. Kametani N. Tokimutsu and K. Miura (1985). A case of Graves' disease with anti-triiodothyronine antibodies. Endocrinol. Japon. in press.

Staeheli, V., M. B. Vallotton and A. Burger (1975). Detection of human anti-thyroxine and anti-triiodothyronine antibodies in different thyroid conditions. J. Clin. Endocrinol. Metab. 41, 669-675.

Tarutani, O., T. Kondo and K. Horiguchi-Sho (1975). The effect of iodide administration on hog thyroid gland and the composition of thyroglobulin and 27-S iodoprotein. Endocrinol. Japon. 22, 389-397.

Trimarchi, F., S. Benvenga, G. Fenzi, S. Mariotti and F. Consolo (1982). Immunoglobulin binding of thyroid hormones in a case of Waldenstrom's macroglobulinemia. $J$. Clin. Endocrinol. Metab. 54, 1045-1050.

Ui, B. and O. Tarutani (1961). Purification of hog thyroglobulin. J. Biochem. 50, 508-518. 